\title{
Vegetation analysis for the rehabilitation of red clay soils at Panchkhal, Kabhrepalanchok District
}

\author{
Sushim R. Baral ${ }^{1}$, Mrigendra B. Malla ${ }^{1}$ and John Howell ${ }^{2}$
}

\begin{abstract}
Vegetation of the four different sites viz. Regenerating sal plot, Plantation plot, Degraded plot and Mixed broad-leaved plot of Bokshe Community Forest of Panchkhal was compared in order to identify the species most potential for rehabilitating degraded red clay soil of the lower Midhills. Amongst the trees, the IVI for Shorea robusta was the highest. Shrubs such as Phoenix humilis, Rhus parviflora, Phyllanthus emblica and Symplocus sp. were highly abundant in the area. Of all the thirty-one herb species recorded, Heteropogon contortus had the highest density in the three plots where there was plenty of sunlight. The greater abundance of species especially in the much exposed and poor sites might indicate the criteria for their selection for the rehabilitation of degraded red soil.
\end{abstract}

Keywords: Vegetation analysis, rehabilitation, degraded land, red soil, soil erosion, Kabhrepalanchok district, Nepal.

$\mathrm{V}$ egetation has long been recognised as an important means of controlling erosion (e.g. Morgan, 1986). It protects the soil from water and wind erosion, acting as a shield against raindrop impact, binding the soil into a resistant root mat and decreasing the erosive energy of flowing water by decreasing its velocity (Emmet, 1970; Striffler, 1979; Holy, 1980). Conversely, a lack of vegetation cover intensifies erosion through structural weakness and an absence of armouring of the soil surface.

The choice of species is a very important element in the reclamation of degraded forest land. Site characteristics closely affect the choice of species. It is obviously important that the species planted can grow satisfactorily in a given site condition. In badly degraded sites, the selection of pioneering species is often necessary. The plants most suitable for this purpose in Nepal are listed in Howell (1999), and include colonising grasses such as Saccharum spontaneum, Cymbopogon microtheca, Eulaliopsis binata, Arunduella nepalensis and Neyraudia arundinacea. Similar lists exist in other parts of the world (PCS, 1983).

In rehabilitating slopes along the Dharan-Dhankuta road and in the Dauney Hills (a Siwalik range in Nawalparasi), the Department of Roads has used naccharum spontaneum, Vitex negundo, Alnus nepalensis, bamboos, and others (Howell et al., 1991). More recent work has established a much wider range of species (Geo-Environmental Unit, 1997; Howell, 1999), but these are mostly applied to debris slopes rather than red clay soils (rato mato in Nepali).

In the mountains of Nepal there is a range of broad categories of degraded land. Areas distinguished by their red soil are relatively common in the densely populated middle mountain and inner Terai terrain. These red soils seem to have specific characteristics and are particularly difficult to rehabilitate. Works related to rehabilitation of degraded areas through the use of plants in various countries including Nepal have been carried out. Despite this, no vegetational analysis of species growing in natural sites has been done in this country to introduce them for the rehabilitation of degraded areas especially those having red soil. The present paper attempts to bridge this gap through determining the state of vegetation in a typical red soil area.

\section{Methodology}

\section{The site}

The present study was conducted at Bokshe Community Forest (approximate altitude of 900 m.), situated in Panchkhal Village Development Committee of Kabhrepalanchok District. The climate is sub-tropical. The natural vegetation is mainly of Shorea robusta (hill sal), which is gradually

\footnotetext{
${ }^{1}$ Department of Forest Research and Survey, PO Box 3339, Kathmandu

2 Living Resources Limited, Durston's Field, Health House, Wedmore, BS26 4UJ,UK
} 


\begin{tabular}{|c|c|c|c|c|c|c|c|}
\hline & \multirow[b]{2}{*}{ Plots } & \multirow[b]{2}{*}{ Quadrate } & \multirow[b]{2}{*}{ Aspect } & \multirow[b]{2}{*}{$\begin{array}{c}\text { Slope } \\
\text { (degree) }\end{array}$} & \multicolumn{3}{|c|}{ Quadrate placed for } \\
\hline & & & & & Trees & Shrubs & Herb \\
\hline 1 & Regenerating sal plot & $A, B, C$ & East & 9 & 3 & 6 & 9 \\
\hline 2 & Plantation plot & $\mathrm{D}, \mathrm{E}$ & East & 8 & 2 & 4 & 6 \\
\hline 3 & Degraded plot & $F, G$ & South-east & 10 & 2 & 4 & 6 \\
\hline & Mixed broad-leaf plot & $\mathrm{H}, \mathrm{I}$ & North & 12 & 2 & 4 & 6 \\
\hline & tal quadrates & & & & 9 & 18 & 27 \\
\hline
\end{tabular}

replaced by Schima-Castanopsis forest up the slope. Planted pines are also found in places.

Within a small area, the site provided a range of typical variations to observe and record the apparent reasons for the existing vegetation cover, particularly the grasses.

\section{Vegetation analysis}

The research site was divided into four distinct plots for the comparison of vegetation. They are:

1. Regenerating sal plot: naturally regenerating Shorea robusta (sal) forest is present on the eastfacing slope. Shorea robusta is the prominent species. The plot is unfenced.

2. Plantation plot: the plantation plot established by the Forest Research and Survey Department to study the growth of a few exotic species such as Acacia auriculiformis, other Acacia species and Cassia species. The plot is fenced, with very good ground cover of grasses.

3. Degraded plot: an area where the soil surface is mostly completely devoid of plants and unshaded by Shorea robusta. A larger proportion of gullies have formed in this area. Shrubs such as Phoenix, Rhus, Pbyllantbus, and very small bushes of Euginia species are present only on raised surfaces and inside the gullies. This plot is unfenced.

4. Mixed broad-leaf plot: this plot is on the north-facing side of a large gully and so is relatively well shaded and moist. The regeneration of Shorea robusta and other broadleaved trees and shrubs has occurred. This plot is also unfenced.

In September 1998, the whole area was examined in detail to enumerate plants. After preparing a list of the species present in the area, quadrate of $10 \times 10$ metres for trees, $5 \times 5$ metres for shrubs and $1 \times 1$ metres for grasses were employed in the respective plots as shown in Table 1.
On each site, a vertical transect was drawn and quadrates of $10 \times 10$ metres were laid randomly at an average interval of twenty metres. Within each major quadrate, the smaller quadrates for shrubs and herb were also laid randomly. Individual species were counted inside each quadrate, tree cover was estimated occularly and the presence or absence of each species inside the quadrate was also recorded. Data were tabulated and calculations made of density, frequency, relative density, relative frequency, relative cover, Importance Value Index according to Zobel et al. (1987). All the species present in the area were collected to make a herbarium for further reference.

\section{Results}

\section{Observations of existing natural conditions}

The following are the main observations made during the site visits.

1. The grass Heteropogon contortus (synomym Cbrysopogon contortus) was frequently found growing either in the shade of trees, or in shallow depressions even without shade. Heteropogon establishes well even in places with relatively high sunlight, as long as there is shade for at least part of the day. For example, beneath a lone tree this species can form a good ground cover.

2. Beneath a few scattered trees such as Shorea robusta and shrubs (e.g. Rbus parviflora and Phoenix humilis), a number of other grasses were seen growing, even if the slopes are otherwise highly exposed to sun.

3. Without a cover of trees or shrubs, the surface of rato mato tends to be very dry and compact. No plants grow on these surfaces except Heteropogon contortus, which grows only where a little top soil has been deposited.

4. No species were found growing on convex areas which shed water relatively fast. 
Table 2: Total species distribution by plot

\begin{tabular}{lcccc}
\hline Plant type & Regenerating sal plot & Plantation plot & Degraded plot & Mixed broad-leaf plot \\
\hline Tree & 1 & 5 & 2 & 4 \\
Shrubs & 14 & 9 & 9 & 7 \\
Herbs & 17 & 20 & 15 & 14 \\
\hline Total & 32 & 34 & 26 & 25 \\
\hline
\end{tabular}

However, grasses are found in areas of water and sediment accumulation.

5. Minor seepage or a very small stream can cause a substantial landslide in deep rato mato where the slope is very steep.

6. In narrow gullies, shrubs (such as Phoenix, Rbus, Pbyllantbus, Symplocus and a few other species) and grasses (Heteropogon, Desmodium, unidentified grass no. 2, and Hedyotis) were usually found growing. Their growth is comparatively better inside the gullies than outside. This is possibly because of one or a combination of better shade, moisture availability, soil nutrients or rooting conditions. These species have not been swept away by water flowing down the gullies. In fact the situation arises where gullies are better vegetated and eroding less than the convex, bare, inter-gully areas.

7. The roots and succulent shoots of Agave americana planted by local farmers in small and narrow gullies have collected a substantial amount of debris.

8. Bhale babiyo (a grass whose botanical name was not identified) establishes well even on very steep landslide head scar slopes.

9. A high rate of regeneration of Cassia species from seeds was observed in the old research plot at Bokshe.

\section{Vegetation analysis}

Table 2 lists the species found in the research site. The number of tree species in the area is relatively low (9 out of 58 species), as is often the case in hill Shorea robusta forest; and of the nine, three (Acacia auriculiformis, another Acacia species and Cassia species) are exotics and one (Pinus roxburgbiz) was a plot). Hence in the old trial plot (i.e. the plantation plot). Hence there were only five naturallyCastanopsis tribulo species: Shorea robusta (sal), jambolina (jamun), Euginiales (musure katus), Euginia Sepium insigne (khirginia nepalensis (kyamun) and old respecies planted in the old research site (the plantation plot), Pinus roxburghii appeared to be the least successful. Shrubs (17 species) were well represented. Of the total number of species found, however, the herbs represent more than fifty percent (31 out of 58).

The pooled data of all species present show that the plantation plot has the highest number of species (34), followed by the sal regeneration plot with 32 species (Table 2).

The lowest number present (25) is in the broad-leaf plot, although there is not much difference from the degraded plot (26). There is only one tree (Shorea robusta) present in the sal regeneration plot.

The number of shrubs was highest in the sal regeneration plot (14) and lowest (7) in the mixed broad-leaf plot. The other two plots had nine each. The number of herbs is highest in the plantation plot (34) and lowest in the mixed broad-leaf plot (25). The difference between the plantation and regenerating sal plots is just two, and between the degraded and mixed broad-leaf plots is just one.

Of the indigenous tree species, Shorea robusta is present in all plots, whereas Pinus roxburgbii is present in the plantation and degraded plots (and had probably been planted in both). Castanopsis and the two Euginia species are present only in the mixed broad-leaf plot, and Sepitum insigne only in the degraded plot. Schima wallichii occurs further up the slope, but not at this altitude.

Table 3 shows that five shrubs, Glochidium species, Indigofera species, Jasminum multiflorum, Phoenix humilis and Pbyllanthus emblica, are present in all plots. Similarly, four species of herbs, Crotalaria species, Cyperus rotundus, Medicago species and Vernonia cineraria, are present in all plots. Heteropogon and Setaria are absent from the mixed broad-leaf plot, perhaps indicating their lack of tolerance of shade.

For the sal regeneration plot, the Importance Value Index is highest for Shorea robusta in the shrub layer, followed by Glochidium, Indigofera, Pbyllantbus emblica, and Phoenix bumilis (Table 4). Except for sal in the plantation plot, the Importance Value Index is high for these species in all of the other plots (Table 4). In the sal regeneration plot, the shrub Indigofera is most common, followed by Randia and Phoenix. Amongst the herbs, the highest frequency (100\%) is 
Banko Janakari, Vol. 10, No. 1

Table 3: Distribution of shrub and herb species in the different plots

\begin{tabular}{|c|c|c|c|c|c|}
\hline S. no. & Species & $\begin{array}{c}\text { Regenerating sal } \\
\text { plot }\end{array}$ & $\begin{array}{c}\text { Plantation } \\
\text { plot }\end{array}$ & $\begin{array}{c}\text { Degraded } \\
\text { plot }\end{array}$ & $\begin{array}{c}\text { Mixed broad- } \\
\text { leaf plot }\end{array}$ \\
\hline \multicolumn{6}{|c|}{ Shrubs } \\
\hline 1 & Asparagus racemosus & + & - & - & - \\
\hline 2 & Cesaria sp. & - & + & - & - \\
\hline 3 & Convolvulus sp & + & - & - & - \\
\hline 4 & Enginia jambolina & - & + & - & - \\
\hline 5 & Flemingia sp & + & - & - & - \\
\hline 6 & Glochidium sp. & + & + & + & + \\
\hline 7 & Indigofera sp. & + & + & + & + \\
\hline 8 & Jasminum multiflorum & + & + & + & + \\
\hline 9 & Phoenix humilis & + & + & + & + \\
\hline 10 & Phyllanthus emblica & + & + & + & + \\
\hline 11 & Randia sp. & + & + & + & - \\
\hline 12 & Rhus parviflora & + & + & + & - \\
\hline 13 & Rhus wallichiana & - & - & + & - \\
\hline 14 & Semecarpus anacardium & + & - & - & - \\
\hline 15 & Shorea robusta $(<3 \mathrm{~m})$ & + & - & - & - \\
\hline 16 & Smilax sp. & - & - & - & + \\
\hline 17 & Symplocus sp. & - & - & + & - \\
\hline 18 & Thepesia sp. & + & - & - & - \\
\hline 19 & Unidentified sp. no. 2 & + & - & - & - \\
\hline 20 & Wendlandia sp. & - & - & - & + \\
\hline \multicolumn{6}{|l|}{ Herbs } \\
\hline 1 & Arthoxon sp & + & - & - & + \\
\hline 2 & Chilianthus sp. (fern) & - & + & - & + \\
\hline 3 & Convolvulus arcinoides & - & + & + & + \\
\hline 4 & Crotalariasp. & + & + & + & + \\
\hline 5 & Cyperus rotundus & + & + & + & + \\
\hline 6 & Cyperus sp. & - & + & - & - \\
\hline 7 & Desmodium sp. & - & + & + & + \\
\hline 8 & Elephanthopus scaber & + & + & - & - \\
\hline 9 & Eragrostris tinella & - & - & + & - \\
\hline 10 & Eupatorium seedlings & - & + & - & - \\
\hline 11 & Galansoga parviflora & - & + & - & - \\
\hline 12 & Ground orchid & - & - & - & + \\
\hline 13 & Hedyotis sp. & - & + & + & - \\
\hline 14 & Heteropogon contortus & + & + & + & - \\
\hline 15 & Imperata cylindrica & + & - & - & + \\
\hline 16 & Justicia sp. & + & + & - & - \\
\hline 17 & Lepidagathis sp. & + & + & - & + \\
\hline 18 & Lucus sp. & + & - & - & + \\
\hline 19 & Medicago sp. & + & + & + & + \\
\hline 20 & Onichium sp. (fern) & - & + & - & + \\
\hline 21 & Paspalum sp. & + & + & - & - \\
\hline 22 & Phoenix humilis & + & - & + & - \\
\hline 23 & Phyllanthus niruri & - & + & - & + \\
\hline 24 & Randia sp. & - & + & + & - \\
\hline 25 & Scutelaria discolor & - & - & - & + \\
\hline 26 & Senesio sp. & + & + & + & - \\
\hline 27 & Setaria sp. & + & + & + & - \\
\hline 28 & Unidentified grass no. 1 & + & - & - & - \\
\hline 29 & Unidentified grass no. 2 & + & + & - & + \\
\hline 30 & Unidentified grass no. 3 & - & - & + & - \\
\hline 31 & Vernonia cineraria & + & + & + & + \\
\hline
\end{tabular}

+ present; - absent 


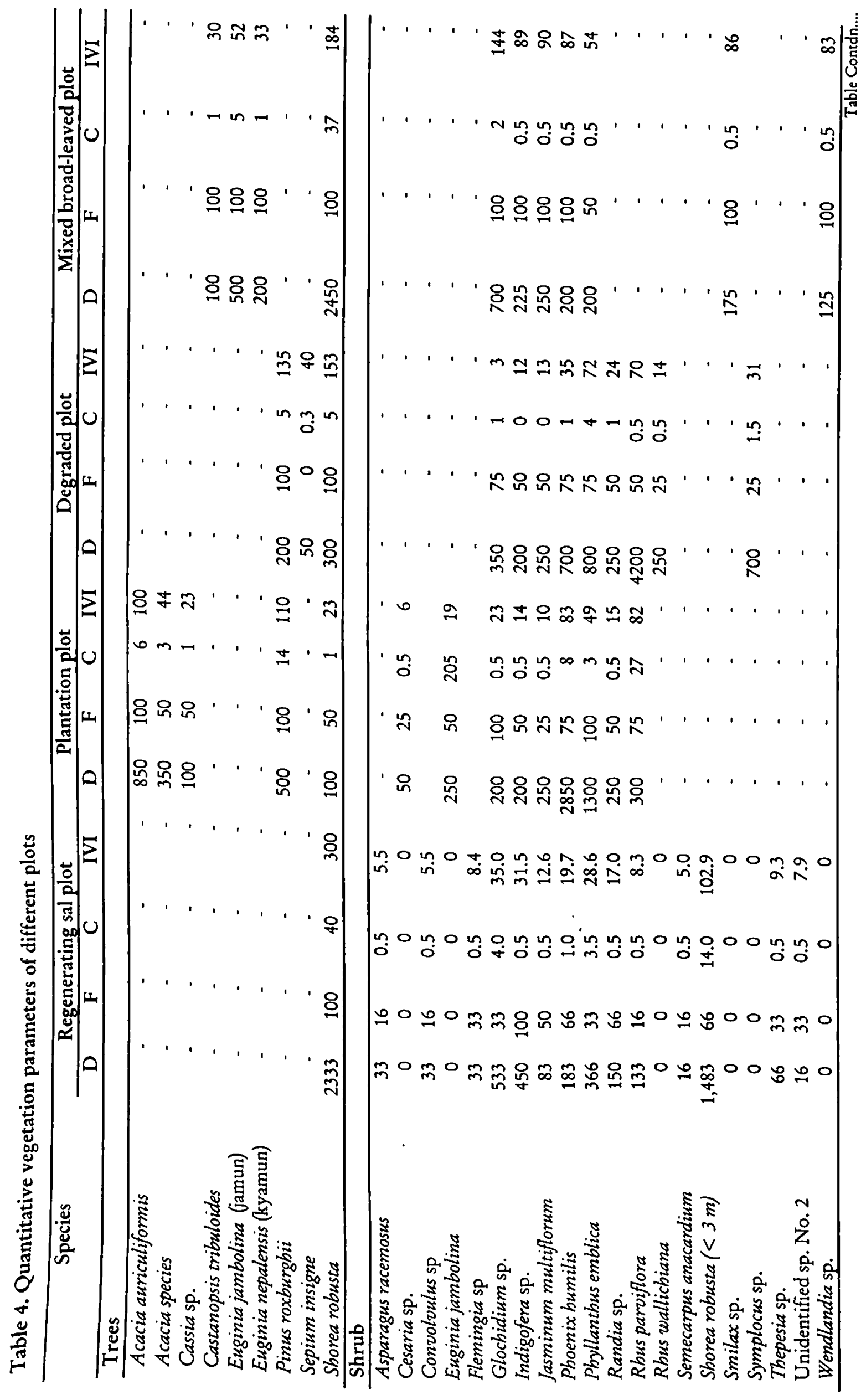




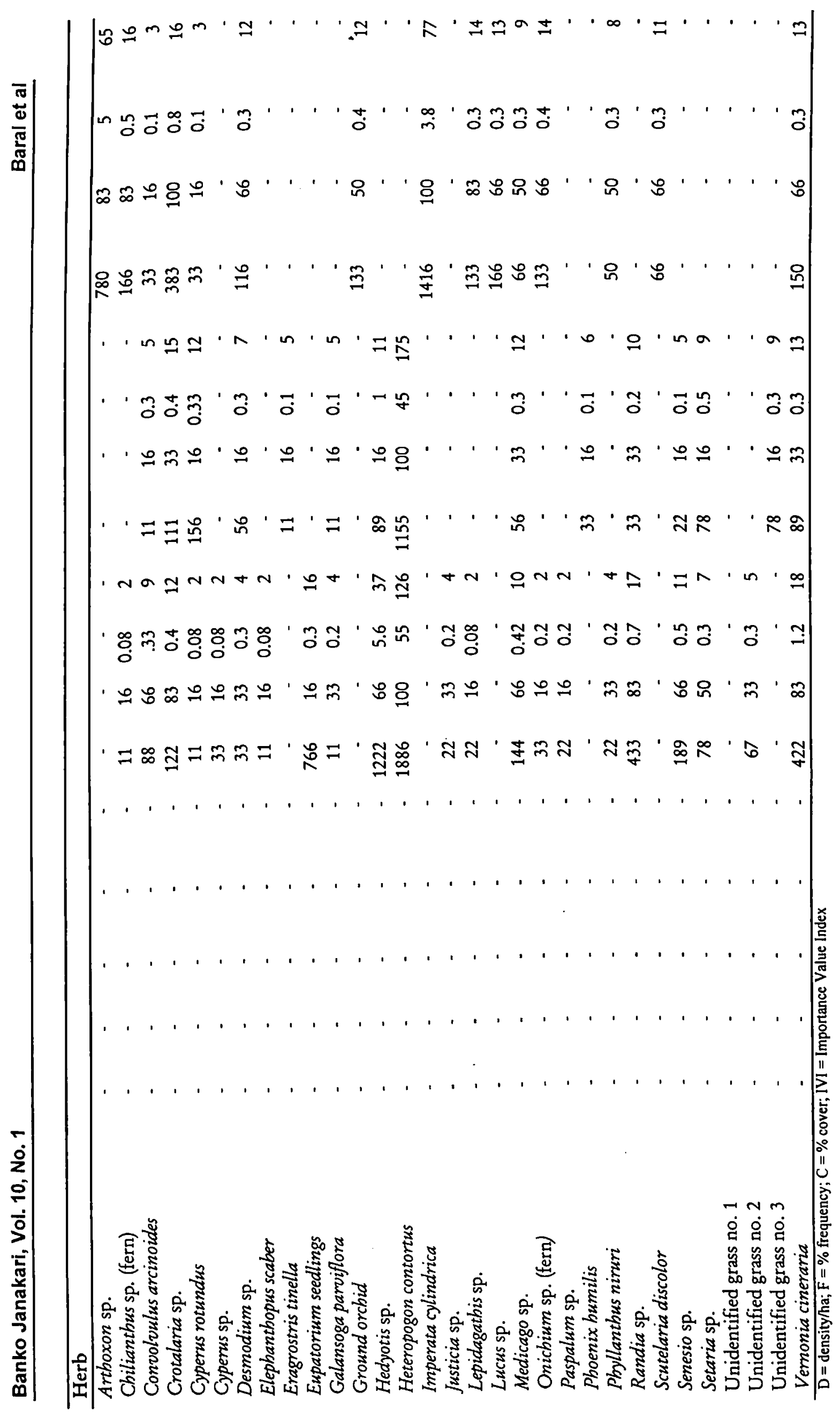


that of Heteropogon. Crotalaria and Arthoxon also fall into the higher frequency class.

The density of trees is in the order:

mixed broad-leaf plot $(3,250 / \mathrm{ha})>$ sal regeneration sal plot $(2,333 /$ ha $)>$ plantation plot $(1,900 /$ ha $)>$ degraded plot (550/ha).

The number of tree species is relatively high (4) in the mixed broad-leaf plot; the regeneration of sal is also greatest in this plot, probably owing to the shady situation and because of the soil deposited in the gully. Although the number of tree species is highest (5) in the plantation plot, the density is lower than in the mixed broad-leaf plot, which could be attributed to the poor performance of the tree plantation.

The pooled density of all the species present in the plots is in the order of plantation plot $(13818 /$ ha $)>$ degraded plot $(10,240 / \mathrm{ha})>$ regenerating sal plot $(9,410 / \mathrm{ha})>$ mixed broad-leaf plot $(8,949 / \mathrm{ha})$.

The high density in the plantation plot may be because of the protection alforded to it by the barbed wire fence erected to protect the old research trial. The surprisingly high density of plants found in the degraded plot seems to be accounted for by the relatively abundant growth of shrubs and herbs in small gullies.

There is no distinct relationship between species density and cover or frequency. In the sal regeneration plot, the only tree species (Shorea robusta) has $40 \%$ ground cover (Table 4 ).

Its understorey of regenerating seedlings have also covered a substantial area of ground (14\%). The other shrubs with high percentages of ground cover are Indigofera, Randia, and Pboenix. Amongst the shrubs, Rhus parviflora has highest relative cover $(62.7 \%)$, and once again Heteropogon has the highest $(55 \%)$ amongst the herbs in the plantation plot (Table 4).

The degraded plot has only $10 \%$ ground cover by the two tree species present (Table 4 ). There is a $4 \%$ ground cover of Pbyllanthus emblica and $25 \%$ of Heteropogon in this plot. This seems to indicate that the larger plants provide enough shade to allow the grasses to succeed even in bare sites. In the mixed broad-leaf plot, Shorea robusta has $37 \%$ ground cover whereas the other three tree species give very little coverage. Both shrubs and herbs also provide little ground cover in this plot (Table 4). The highest Importance Value Indices are 183 for Shorea robusta, 143 for the shrub Glocbicium and 76.6 for the grass Imperata cylindrica (Table 4).

\section{Discussion}

It is clear that the research site is a degraded forest, but that the degree of degradation varies considerably between the plots. This agrees with the general assessment of rato mato made by Shah and Schreier (1992).

The area has an annual rainfall of around $1050 \mathrm{~mm}$. The rate of evapotranspiration in this area exceeds precipitation between October and March (Jackson, 1994), and so moisture stress, a strong factor limiting growth is pronounced during this long, dry period.

In terms of site moisture, the combined effects of aspect, soil condition and forest cover appear to give this gradation from moist to dry between the four plots.

Mixed broad-leaf plot (More moist) $>$ sal regeneration plot $>$ plantation plot $>$ degraded plot (Drier).

The plantation plot also has a reasonable plant cover which must help to lessen the moisture stress.

The degraded plot certainly appears to be the most difficult location for plant growth. The dryness is almost certainly related to its south-easterly aspect and almost bare surface: in some of the replicate quadrats, there were no shrubs or herbs at all. Degradation usually takes a relatively long time, perhaps twenty-five years in the case of Bokshe, but must vary enormously depending on the pressures on the forest.

Following protection and plantation, the slow process of rehabilitation reverses degradation. The trees in the plantation plot were planted about fifteen years before this study was made, and there are signs of top soil amelioration starting. However, it still had far to go before reaching the level of the sal regeneration plot. It can be supposed that canopy closure would take a long time to be completed on an exposed, hot and dry site such as this, but that soil amelioration might speed up once this has been achieved. Basic management considerations would also affect the speed of rehabilitation, and for the research site these are impossible to conjecture. For example, we have no way of telling reliably how much leaf litter has been collected from the plantation plot, but this might have a significant impact on the condition of the soil.

The rehabilitation of sites of this nature demands a careful choice of appropriate plants. Local species are generally to be preferred for this purpose. There 
should also be a general debate as to whether to start with trees, shrubs or herbs. In traditional soil conservation, it is often common to plant trees first; these facilitate the growth of shrubs and herbs. In the form of bio-engineering used by the Department of Roads, grasses are usually favoured as the initial plants on debris slopes. Both have their different drawbacks, and neither has shown complete success on rato mato.

Of all the thirty-one herb species recorded in this study, Heteropogon contortus (locally known as khar ghans) has the highest density in the three plots where there is plenty of sunlight; but this species is absent from the shaded gully (the mixed broad-leaf plot). This shorvs clearly that this grass dislikes heavy shade, but grows even on highly exposed and dry surfaces as long as there is shade for part of the day. Its highest density $(1,866 / \mathrm{ha})$ is in the plantation plot, followed by $1,456 / \mathrm{ha}$ and $1,155 / \mathrm{ha}$ in the sal regeneration and degraded plots respectively. It thrives on bare soil surfaces without any shade, where loose and friable topsoil has been deposited in depressions. It often forms a good soil cover around trees, on harder surfaces, but is restricted to the shade or partial shade areas. Under diffused light it grows well on slopes even without depressions. The absolute frequency of this species at all the three plots, as well as its presence in the other areas visited for observations, indicates its importance as one of the best available coloniser species.

The presence of only five species of shrubs (Glocbidium species, Indigofera species, Jasminum multiflorum, Phoenix bumilis and Pbyllanthus emblica) in all plots may be taken as an indication that there are very few shrubs which can grow successfully in poor sites of this nature. These five appear to have a wide tolerance of poor soil and different shade conditions, and therefore represent promising indigenous species which could be of use in rehabilitating degraded rato mato.

It is possible to draw up criteria for the selection of species for the rehabilitating of degraded rato mato sites. These may include: (i) ability to grow on poor rato mato sites, including hot, exposed and dry micro-site conditions; (ii) fast growing, with a high rate of biomass production; (iii) nitrogen fixing; (iv) coppicing ability; and (v) preferred by the local community or users.

Ranking these criteria depends on local conditions and should not be generalised. For Bokshe, the combination of the first and last of these criteria would seem to be most appropriate.

\section{Acknowledgement}

The research leading to this paper was commissioned by the Department of Roads and was funded by the UK Department of International Development under the Nepal/UK Road Maintenance Project. Prof. P. K. Jha is acknowledge for comments and Mr. Kuber J. Malla for species identification.

\section{References}

Emmet, W. W. 1970. The hydraulics of overland flow on hillslopes. United States Geological Survey Professional Paper 662A.

Geo-Environmental Unit. 1997. Bio-engineering Information. Department of Roads, Kathmandu.

Holy, M. 1980. Erosion and Environment. Pergamon Press, Oxford.

Howell, J. H. 1999. Roadside Bio-engineering. Department of Roads, Kathmandu.

Howell, J. H., Clark, J. E., Lawrance, C. and Sunwar, I. 1991. Vegetation Structures for Stabilising Highway Slopes. Department of Roads, Kathmandu.

Jackson, J. K. 1994. Manual of Afforestation in Nepal. Forestry Research and Survey Centre, Kathmandu.

Morgan, R P C. 1986. Soil Erosion and Conservation. Longman Scientific and Technical, Harlow.

PCS. 1983. Reclamation and Environmental Grasses. Pacific Coast Seed Inc. 7074 D Commerce Circle Pleasanton, CA 94566.

Shah, P. B. and Schreier, H. 1992. Nutrient deficiency and soil fertility issues. In Proceedings on Soil Fertility and Erosion Issues in the Middle Mountains of Nepal (eds. P B Shah, K W Riley, $\mathrm{H}$ Schreier and S J Brown). Integrated Survey Section and the University of British Columbia, Canada.

Striffler, W. D. 1979. Watershed planning and management. In Planning the uses and management of land (eds M. T. Beaty, G. W. Petersen and L. D. Swindale), Agronomy Series 21. American Society of Agronomy, Madison.

Zobel D. B., Jha, P. K., Behan, M. J. and Yadav, U. K. R. 1987. A Practical Manual for Ecology. Ratna Book Distributors, Kathmandu. 